\title{
Molecular assessment of the species of Gracilariaceae (Gracilariales, Rhodophyta) from the Yucatan Peninsula, MeXICO, InCluding two neW ReCORdS for the Mexican AtLantic

\author{
Evaluación molecular de las especies de Gracilariaceae (Gracilariales, \\ Rhodophyta) en la Península de Yucatán, México, incluyendo dos nuevos \\ REGISTROS PARA EL ATLÁNTICO MEXICANO
}

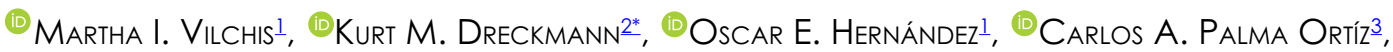 \\ (1) María luisa Núñez Resendiz $\stackrel{2}{2}$ and ${ }^{\circledR 0}$ Abel Sentíes? 2
}

\author{
' Doctorado en Ciencias Biológicas y de la Salud, Universidad Autónoma Metropolitana-Iztapalapa, Ciudad de México, México \\ ${ }^{2}$ Departamento de Hidrobiología, Universidad Autónoma Metropolitana-Iztapalapa, Ciudad de México, México \\ ${ }^{3}$ Maestría en Biología, Universidad Autónoma Metropolitana-Iztapalapa, Ciudad de México, México \\ *Corresponding author: tuna@xanum.uam.mx
}

\begin{abstract}
Background. The Gracilariaceae is one of the most diverse and abundant families of marine red algae. Most species in this family exhibit high morphological variability and overlapping of characters. In the Yucatan Peninsula 30 species have been historically recorded, but the phylogenetic identity for many of them is still unknown.

Questions: Is the current diversity of the family in the area overestimated?

Studied species: Crassiphycus caudatus, C. corneus, C. usneoides, Gracilaria flabelliformis, G. hayi, G. cf isabellana, G. microcarpa, G. occidentalis, G. suzanneae, Gracilariopsis tenuifrons.

Study site and dates: Campeche: km 33 carretera Champotón, Bahía Tortuga, Puente Xen Kan III, Punta Xen, Sabancuy, 2017, 2018; Yucatan: Puerto Sisal, Puerto Progreso, Puerto Chicxulub, Puerto Telchac, 2018; Quintana Roo: Playa 88, Xcalacoco, Punta Esmeralda, 2019.

Methods. Phylogenetic analysis (with COI-5P and $r b c \mathrm{~L}$ sequences), supported by DNA species delimitation methods, genetic distances and morphological comparisons, allowed us to molecularly identify the specimens collected.

Results. The phylogenetic identity of 10 species of Gracilariaceae was confirmed, two of which are new records for the Mexican Atlantic: $G$. hayi and G. suzanneae.

Conclusion. The study demonstrated that the molecular assessment has proved to be very useful for the diversity evaluation, thus, the future phylogenetic identifies for the rest of morphospecies recorded in the area will allow a better approximation of Gracilariaceae diversity species. Key words: COI-5P, diversity, morphospecies, phylogeny, $r b c \mathrm{~L}$.

\section{Resumen}

Antecedentes. Gracilariaceae es una de las familias más diversas y abundantes de algas rojas marinas, la mayoría de sus especies exhiben una alta variabilidad morfológica y superposición de caracteres. En la Península de Yucatán se han registrado 30 especies, pero aún se desconoce la identidad filogenética de muchas de ellas.

Preguntas: ¿Se sobreestima la diversidad actual de la familia en el área?

Especies de estudio: Crassiphycus caudatus, C. corneus, C. usneoides, Gracilaria flabelliformis, G. hayi, G. cf isabellana, G. microcarpa, G. occidentalis, G. suzanneae, Gracilariopsis tenuifrons.

Sitios y años de estudio: Campeche: km 33 carretera Champotón, Bahía Tortuga, Puente Xen Kan III, Punta Xen, Sabancuy, 2017, 2018; Yucatan: Puerto Sisal, Puerto Progreso, Puerto Chicxulub, Puerto Telchac, 2018; Quintana Roo: Playa 88, Xcalacoco, Punta Esmeralda, 2019.

Métodos. Análisis filogenéticos (con secuencias COI-5P y $r b c \mathrm{~L}$ ), apoyados por métodos de delimitación de especies de ADN, distancias genéticas y comparaciones morfológicas, permitió identificar molecularmente cada especie recolectada.

Resultados. Se confirmó la identidad filogenética de 10 especies de Gracilariaceae, dos de las cuales fueron nuevos registros para el Atlántico mexicano: G. hayi y G. suzanneae.

Conclusión: El presente estudio demostró que la evaluación molecular resultó ser muy útil para la estimación de la diversidad, por lo que futuras identificaciones filogenéticas para el resto de las morfoespecies registradas en el área, permitirán una mejor aproximación de la diversidad de las especies de Gracilariaceae.

Palabras clave: COI-5P, diversidad, filogenia, morfoespecies, $r b c \mathrm{~L}$.
\end{abstract}


he Gracilariaceae Nägeli is one of the most diverse and abundant families of marine red algae. The family is currently composed of 242 species, grouped into nine genera, widely distributed in temperate-tropical waters throughout the world (Guiry \& Guiry 2021), with the highest species richness concentrated in the subtropical and tropical regions (Dreckmann \& Sentíes 2014, Lyra et al. 2015a). In that several of their members are commercially important and widely cultivated to produce agar (Oliveira et al. 2000), the systematics of the group has been relatively well studied (Gurgel \& Fredericq 2004, Lyra et al. 2015a, 2015b, 2016, 2021, Gurgel et al. 2003, 2018, Guiry et al. 2018). However, although the monophyly of Gracilariaceae is well-supported by molecular data (Gurgel et al. 2018, 2020), the morphological recognition of the species continues to be a difficult task and, in some cases, almost impossible because most species exhibit high morphological variability, leading to unclear species circumscriptions and an overlapping of characters (Bird \& McLachlan 1982, Santelices \& Valera 1993, Lyra et al. 2015a, Núñez-Resendiz et al. 2015). This overlapping has led to the uncovering of cryptic species (Saunders 2009) and confusion in their identification and geographic distribution ranges (Byrne et al. 2002, Cohen et al. 2004, Dreckmann et al. 2018, Vilchis et al. 2019), which currently generates an underestimation or overestimation of the actual diversity of species in the family (Dreckmann 2012, Dreckmann \& Sentíes 2014). Different molecular markers have been successfully employed in studies of the Gracilariales allowing for the elucidation of species boundaries, phylogenetic relationships, and the recognition of new species (Kim et al. 2008, Yang et al. 2008, 2013, Muangmai et al. 2014a,b, Ardito et al. 2017, Hardesty \& Freshwater 2018, Le et al. 2020).

On the coast of the Yucatan Peninsula, 30 species of Gracilariaceae, assigned to three genera, have been recorded under the morphospecies concept: Crassiphycus caudatus (J. Agardh) Gurgel, J.N. Norris \& Fredericq, C. corneus (J. Agardh) Gurgel, J.N. Norris \& Fredericq, C. crassissimus (P. Crouan \& H. Crouan) Gurgel, J.N. Norris \& Fredericq, C. usneoides (C. Agardh) Gurgel, J.N. Norris \& Fredericq, Gracilaria apiculata P. Crouan \& H. Crouan, G. armata (C. Agardh) Greville, G. blodgettii Harvey, G. bursa-pastoris (S.G. Gmelin) P.C. Silva, G. cervicornis (Turner) J. Agardh, G. cuneata Areschoug, G. curtissiae J. Agardh, G. cylindrica Børgesen, G. damicornis J. Agardh, G. debilis (Forsskål) Børgesen, G. domingensis (Kützing) Sonder ex Dickie, G. flabelliformis (P. Crouan \& H. Crouan) Fredericq \& Gurgel, G. foliifera (Forsskål) Børgesen, G. gracilis (Stackhouse) Steentoft, L.M. Irvine \& Farnham, G. mammillaris (Montagne) M. Howe, G. microcarpa Dreckmann, Núñez-Resendiz \& Sentíes, G. ornata Areschoug, G. tikvahiae Mc Lachlan, G. venezuelensis W.R. Taylor, G. wrightii (Turner) J. Agardh, Gracilariopsis andersonii (Grunow) E.Y. Dawson, Gp. cata-luziana Gurgel, Fredericq \& J.N.Norris, Gp. costaricensis E.Y. Dawson, Gp. longissima (S.G. Gmelin) Steentoft, L.M. Irvine \& Farnham, Gp. tenuifrons (C.J. Bird \& E.C. Oliveira) Fredericq \& Hommersand and Gp. sjoestedtii (Kylin) E.Y. Dawson (Gurgel et al. 2003, Ortega et al. 2001, Dreckmann 2012, Dreckmann \& Sentíes 2014, García-García et al. 2020). Although there are detailed morphological and biogeographic studies for these species, for which an overestimation of the current diversity was already suggested (Dreckmann 2012, Dreckmann \& Sentíes 2014), there is molecular support only for Crassiphycus corneus, C. usneoides, Gracilaria macrocarpa, and Gracilariopsis tenuifrons (Núñez-Resendiz et al. 2015, Dreckmann et al. 2018, Hernández et al. 2020). These studies have been carried out with molecular markers ( $r b c \mathrm{~L}$ and COI-5P), which have allowed the recognition of cryptic diversity (Núñez-Resendiz et al. 2015, 2016), the description of new species (Dreckmann et al. 2018) and the redefinition of their areas of distribution (Hernández et al. 2020). However, the phylogenetic identity for many of the species of Gracilariaceae recorded in the area is still unknown.

Our aim in the present study was to determine the phylogenetical identity of nine morphospecies in Gracilariaceae previously collected by authors at the Yucatan Peninsula, using molecular-assisted alpha taxonomy approaches.

\section{Material and methods}

Fifty samples, consisting of compressed, flattened, and cylindrical specimens, identified as morphospecies of Gracilariaceae (Table S1) according to Dreckmann (2012), were collected in 12 localities along the Yucatan Peninsula, at a depth of 1.5-2.0 m, in three different years (Table S1). Apical sections for molecular analysis were preserved in silica gel until DNA extraction was done. Samples collected for morphological observations were preserved in $3 \%$ 
formaldehyde in seawater. Fresh specimens of each species were mounted on herbarium sheets and incorporated into the algal collections under a single voucher number, if they were collected in a same site and date (Table S1), at Metropolitan Herbarium UAMIZ (Herbarium abbreviations follow the online Index Herbariorum sciweb.nybg.org/ science2/IndexHerbariorum.asp).

Total DNA for molecular analysis was extracted from 5-10 mg of dried tissue using a Qiagen DNeasy Plant Mini Kit (Qiagen, Valencia, California USA) according to the manufacturer's protocols. The mitochondrial COI-5P region was amplified using the primers GazF1 and GazR1 (Saunders 2005). The chloroplast $r b c \mathrm{~L}$ region was amplified using the primers F8 (Shimada et al. 1999), R753 (Freshwater \& Rueness 1994), and F765 (Wang et al. 2000) R1381 (Freshwater \& Rueness 1994). The PCR procedure followed Núñez-Resendiz et al. (2015). PCR products were purified with QIAquick Gel Extraction Kit (Qiagen, Valencia, California USA) and sequenced commercially (Macrogen Inc., Seoul, Korea). The same set of primers was used for sequencing. The sequences generated were assembled and edited using the program Sequencher ${ }^{\circledR}$ version 5.4.5. The final alignment with sequences from GenBank of other species of Gracilariaceae (Table S2) was performed using Bioedit (Hall 1999). Cryptonemia seminervis (C. Agardh) J. Agardh and Laurencia mutueae Sentíes, Cassano \& Dreckmann were included as outgroup in both data sets. We analysed the COI-5P and $r b c \mathrm{~L}$ data sets separately. Phylogenetic analyses using maximum likelihood (ML) and Bayesian inference (BI) were performed separately with partitioned codons. The evolutionary model selected was GTR $+\mathrm{I}+\mathrm{G}$ (general time reversible + invariable sites + gamma distribution) determined based on the Maximum Likelihood ratio test implemented by TOPALi version 2 software (Milne et al. 2009). ML analysis was performed using RAxML software (Stamatakis 2006) with the GTR $+\mathrm{I}+\mathrm{G}$ model. Support for each branch was obtained from 1000 bootstrap replications. BI analysis was performed using MrBayes 3.2.2 (Ronquist et al. 2012). Four chains of Markov chain Monte Carlo were used, starting with a random tree, and sampling the data every 500 generations for $5 \times 10^{6}$ generations. $25 \%$ of trees were discarded as burn-in. Pairwise distances values (p distance) were calculated using Mega X (Kumar et al. 2018).

To delimit the Gracilariaceae species in the trees, we ran three DNA - based species delimitation methods for both data sets (COI-5P and $r b c \mathrm{~L}$ ): Automatic Barcoding Gap Discovery (ABGD) (Puillandre et al. 2012), Bayesian variant of Poisson Trees Processes model (bPTP) (Pons et al. 2006), and the General-Mixed-Yule-Coalescent (GMYC) (Zhang et al. 2013). The ABGD method was done in the web interface (bioinfo.mnhn.fr/abi/public/abgd/abgdweb. $\underline{\mathrm{html}}$ ), with the following criteria: intraspecific variability (P) between 0.001 (Pmin) and 0.1 (Pmax), minimum gap width $(\mathrm{X})$ of 0.1 , Kimura-2-parameters, 50 screening steps and $20 \mathrm{Nb}$ bins. The bPTP model was done via interface web (species.h-its.org/ptp), using the ML topology (see above). The analysis consisted of 100,000 generations, with a thinning every 100 generations and a burn-in of $25 \%$. For GYMC analyses, we generated an ultrametric tree for GYMC analyses in BEAST 1.8.2 software (Drummond et al. 2012), from $r b c \mathrm{~L}$ and COI-5P after removing identical sequences in the alignments. A coalescent constant size tree prior was set under an uncorrelated lognormal relaxed clock and GTR $+\mathrm{G}+\mathrm{I}$ site model. The analysis was set up for 10 million generations and a sampling frequency of 5000 . Before performing the GMYC analyses, we checked the estimated samples size with Tracer 1.6 (Rambaut et al. 2014). The maximum clade credibility tree was computed using TreeAnnotator v1.8.3 (Drummond et al. 2012). The resulting ultrametric tree was imported into the GMYC web server (species.h-its.org/gmyc), running the single threshold.

Photographs of thalli were taken with a Nikon D7000 digital camera. Microscopic cross-sections were made by hand using a razor blade and mounted in $80 \% \mathrm{Karo}^{\circledR} /$ distilled water solution. Photomicrographs were taken using an Olympus DP12 digital camera adapted to an Olympus BX51 microscope (DIC and bright-field). Morphological measurements were obtained from micrographs using SigmaScan ${ }^{\odot}$ Pro automated image analysis software (Jandel Scientific, Sausalito, California).

\section{Results}

From our results with COI-5P and $r b c \mathrm{~L}$ sequences, supported by DNA species delimitation methods and genetic distances, we were able to confirm the phylogenetic identity of ten species of Gracilariaceae (Figures $1, \underline{2})$ distributed 
in the Yucatan Peninsula. Of the nine Gracilariaceae morphospecies, only Crassiphycus corneus, C. usneoides and Gracilariopsis tenuifrons confirmed their phylogenetic identity, while the remaining of morphospecies correspond to another identity, and are mentioned below: the samples identified as Gracilaria blodgettii and G. tikvahiae correspond to G. microcarpa; the samples identified as G. damicornis correspond to G. flabelliformis; the samples identified as G. mammillaris correspond to G. flabelliformis, G. occidentalis, G. hayi or G. suzanneae; the samples identified to Crassiphycus caudatus and $G$. cf. isabellana could be correspond to new phylogenetic identities. We have recognized eight species previously recorded in the area: Crassiphycus caudatus, C. corneus, C. usneoides, Gracilaria flabelliformis, G. cf. isabellana, G. microcarpa, G. occidentalis, and Gracilariopsis tenuifrons; and two species were new records for the Mexican Atlantic: G. hayi and G. suzanneae.
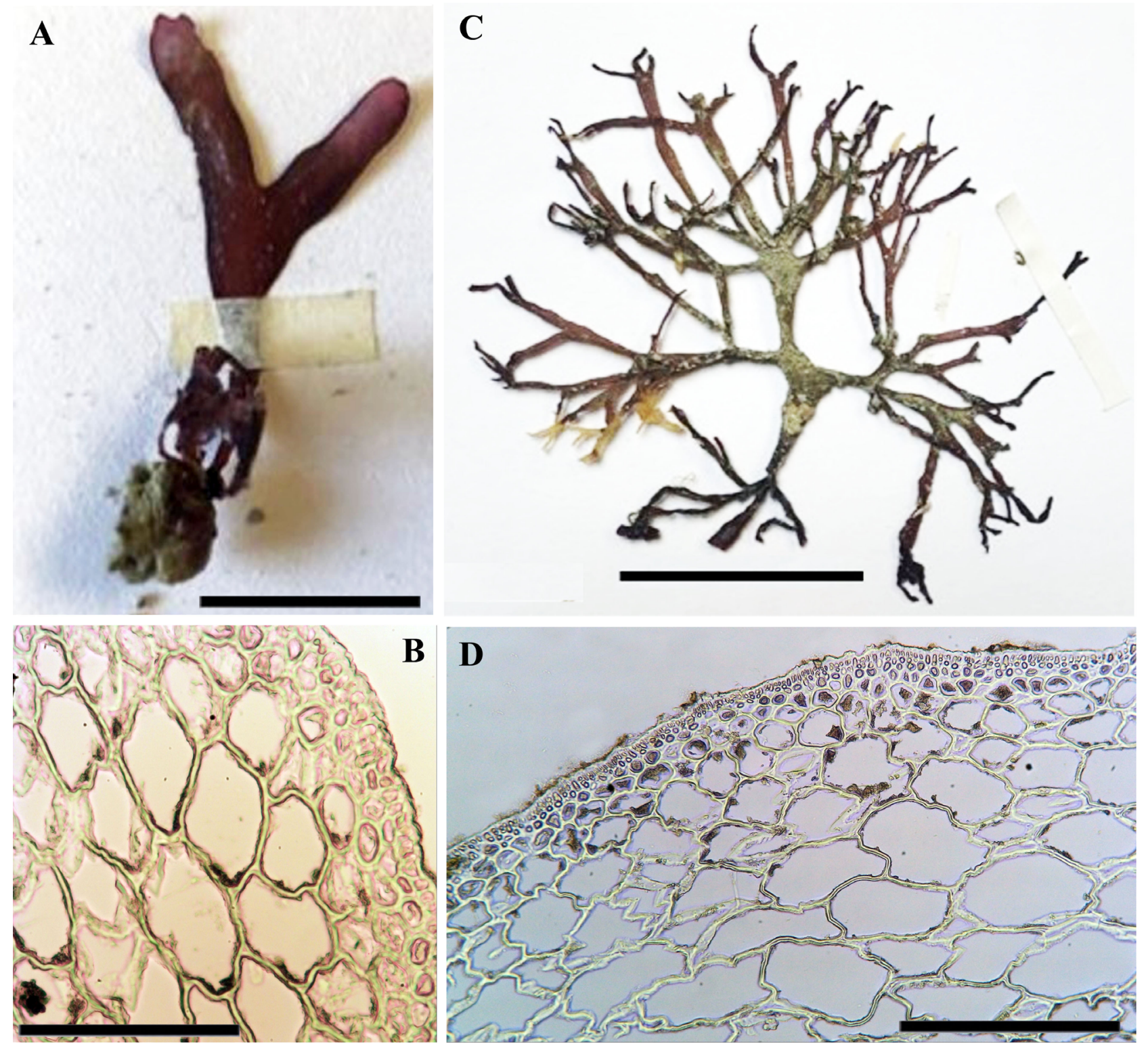

Figure 1. A. G. hayi from Bahía Tortuga. UAMIZ-1425. Scale bar $=4 \mathrm{~cm}$. B. Cross section of G. hayi showing cortical and medullary cells. UAMIZ-1425. Scale bar $=60 \mu \mathrm{m}$. C. G. suzanneae from Punta Xen. Scale bar $=4 \mathrm{~cm}$. UAMIZ-1412. D. Cross section of G. suzanneae showing cortex and medullary cells. UAMIZ-1412. Scale bar $=60 \mu \mathrm{m}$. 


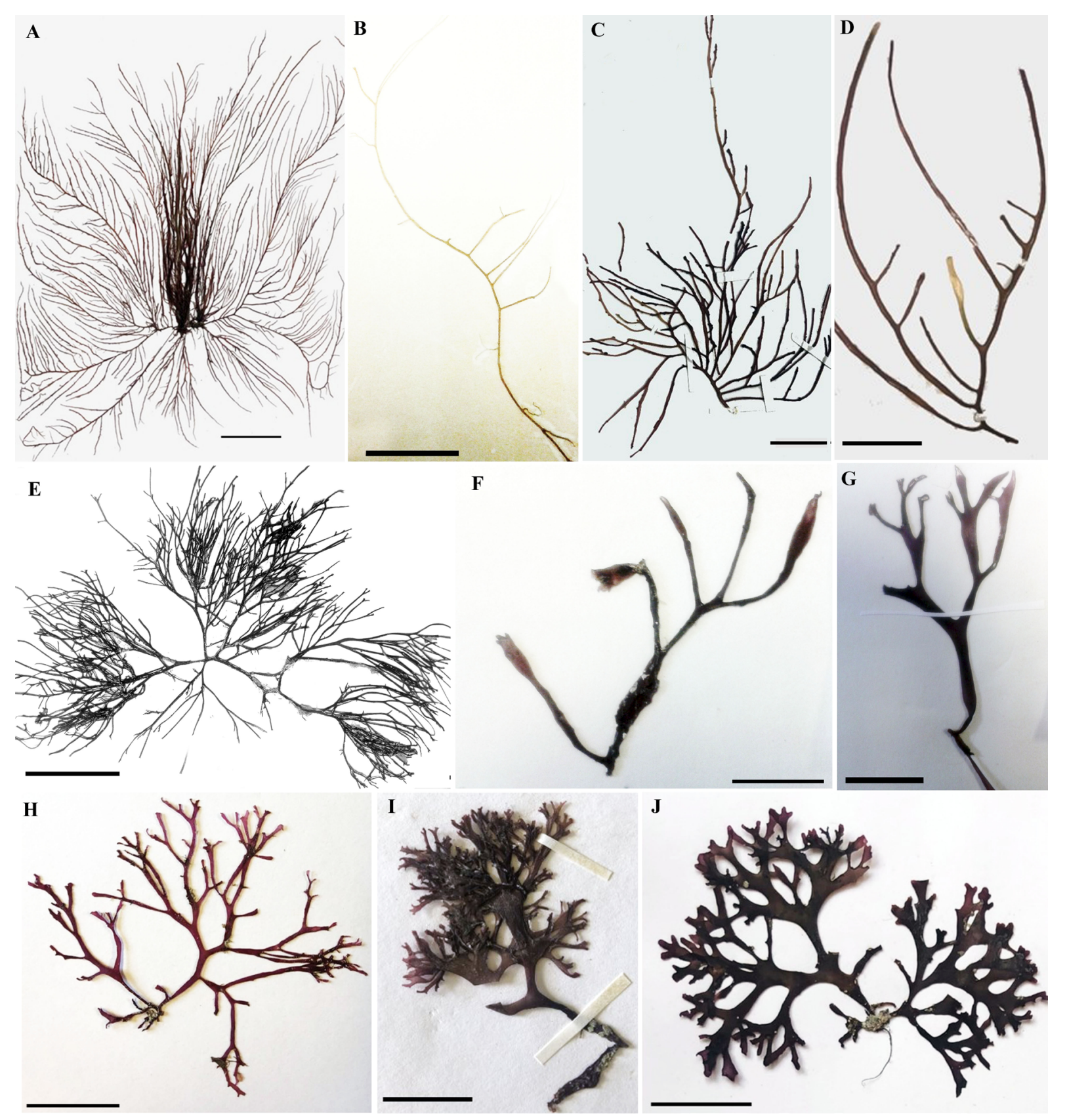

Figure 2. A. Gracilariopsis tenuifrons from Cancún. UAMIZ-1415. Scale bar $=10 \mathrm{~cm}$. B. Crassiphycus caudatus from Bahía Tortuga. UAMIZ-1416. Scale bar $=2.5 \mathrm{~cm}$. C. corneus from Puerto Progreso. UAMIZ-1417. Scale bar $=4 \mathrm{~cm}$. D. C. usneoides from Puerto Progreso. UAMIZ-1420. Scale bar $=4$ cm. E. Gracilaria microcarpa from Punta Xen. Scale bar $=4$ cm. UAMIZ-1409. F-G. G. cf isabellana from Km 33 Carretera Champotón. UAMIZ-1431. Scale bar $=1 \mathrm{~cm}$. H. G. occidentalis from Punta Xen. UAMIZ-1426. Scale bar = 4cm. I. G. flabelliformis from Bahía Tortuga. UAMIZ-1411. Scale bar $=4 \mathrm{~cm}$. I. G. flabelliformis from Xcalacoco. UAMIZ-1429. Scale bar $=3 \mathrm{~cm}$.

Gracilaria hayi Gurgel, Fredericq \& J.N.Norris in Gurgel et al. 2004; 178, figure 7 A-F (Figures 1A-B). Thallus flattened, $5 \mathrm{~cm}$ long, dark red (Figure 1A). Dichotomous branching in one plane. Branches flattened up to $1 \mathrm{~cm}$ wide, non-constricted at the base, smooth margins, rounded apices (Figure 1A). Thalli not adhering to paper. Gradual transition between medulla and cortex. Cortex with 1-2 cell layers, cells oval to round, 5-10 $\mu \mathrm{m}$ in diameter (Figure $\underline{1 B})$. Subcortex composed of 2 cell layers, cells oval of 26-44 $\mu \mathrm{m}$ in diameter (Figure 1B $)$. Medulla of 2-3 cell layers, 
cells oval to round, 120-170 $\mu \mathrm{m}$ in diameter (Figure 1B). Reproductive characters were not observed in sequenced specimens.

Gracilaria suzanneae L.P.Soares, C.F.D.Gurgel \& M.T.Fujii in Soares et al. 2018; 346, 347, figures 1-22 (as 'suzannae') (Figures 1C-D). Thallus flattened, $8 \mathrm{~cm}$ long, brown with reddish apices, coriaceous texture (Figure 1C). Trichotomous to irregular branching. Branches flattened, 2-3 cm long, 1-7 mm wide, non-constricted at the base (Figure $\underline{1 C})$. Apical branches with a lacerate appearance. Thalli not adhering to paper. Cortex with 2-4 cell layers, cells oval to rectangular, 5-27 $\mu \mathrm{m}$ in diameter (Figure 1D). Subcortex composed of 1-2 cell layers, cells oval of 19-49 $\mu \mathrm{m}$ in diameter (Figure 1D). Medulla of 2-3 cell layers, cells oval to round, 206-250 $\mu \mathrm{m}$ in diameter (Figure 1D). Reproductive characters were not observed in sequenced specimens.

The COI-5P alignment was 614 base pairs (bp) in length and included 55 sequences, 29 newly determined; $r b c \mathrm{~L}$ alignment was 1,204 bp in length and included 69 sequences, 30 newly determined. With both markers, ML and BI analyses had identical topologies; only ML tree, with BI values integrated and ML bootstrap values are shown (Figures 3, 4). The topologies resulting with both markers showed that our specimens were included in three monophyletic groups (I, II, III). Group I, with the maximum phylogenetic support in both analyses, was integrated with the species of the genus Gracilariopsis (Figures 3, 4). Of all the specimens collected, identified morphologically in the field as Gracilariopsis, only the presence of Gp. tenuifrons was confirmed with a distribution from Campeche to Quintana Roo. Group II, with high support (COI-P, BI = 1.0, $\mathrm{ML}=99 \%$; $r b c \mathrm{~L}, \mathrm{BI}=1.0, \mathrm{ML}=100 \%$ ), included species of the genus Crassiphycus, and the presence of three species was confirmed (Figures 3, 4): C. caudatus with distribution in Campeche; $C$. corneus and C. usneoides distributed along the three States of the Yucatan Peninsula. Group III, also well-supported (COI-P, BI $=1.0, \mathrm{ML}=97 \% ; r b c \mathrm{~L}, \mathrm{BI}=0.99, \mathrm{ML}=99 \%$ ), included the species of the genus Gracilaria, and six species were confirmed (Figures 3, 4): G. flabelliformis distributed from Campeche to Quintana Roo; G. hayi distributed in Campeche; G. cf isabellana distributed in Quintana Roo; G. microcarpa distributed from Campeche to Quintana Roo; G. occidentalis distributed in Campeche; and G. suzanneae distributed in Campeche.

Genetic distance within the species of the Gracilariaceae included in our analyses varied between the recognized genera. Species of Gracilaria ranged from $4.2 \%$ (G. occidentalis from Mexico) to 17.6\% (G. dentata from Senegal) with COI-5P and from $0.8 \%$ (G. suzanneae from Brazil) to $6.5 \%$ (G. isabellana from Mexico) with $r b c \mathrm{~L}$. Species of Crassiphycus ranged from $5.2 \%$ (C. usneoides from Mexico) to $10.3 \%$ (C. caudatus from Brazil) with COI-5P and from $2.1 \%$ (C. corneus from Venezuela) to $3.1 \%$ (C. usneoides from Mexico) with rbcL. Species of Gracilariopsis ranged from $5.2 \%$ (Gp. andersonii from Canada) to $6.5 \%$ (Gp. tenuifrons from Brazil) with COI-5P and from $3.3 \%$ (Gp. lemaneiformis from Mexico) to $3.6 \%$ (Gp. costaricensis from Costa Rica) with $r b c \mathrm{~L}$.

In addition, for COI-5P data set, ABGD analysis defined 26 hypothetical species (nine of these from Yucatan Peninsula), and bPTP and GYMC analyses defined 24 (seven of these are from Yucatan Peninsula). For $r b c \mathrm{~L}$ data set, ABGD analysis defined 22 hypothetical species (eight of these are from Yucatan Peninsula), and bPTP and GYMC analyses defined 24 (seven of these from Yucatan Peninsula).

\section{Discussion}

Based on his review with morphological data and geographic distribution of the species of Gracilariaceae occurring on the Mexican Atlantic coast, Dreckmann (2012) concluded that the diversity of the family in the area was overestimated. Consequently, he proposed that from the 30 species that had currently been recorded in the Yucatan Peninsula, only 12 species were distributed in the area: five species of Gracilaria (G. blodgettii, G. cervicornis, G. damicornis, G. mammillaris, and G. tikvahiae), four species of Crassiphycus (as Hydropuntia Montagne) (C. caudatus, C. corneus, C. usneoides, and C. crassus), and three species of Gracilariopsis (Gp. cata-luziana, Gp. lemaneiformis and $G$ p. tenuifrons). These data were later confirmed in a new review of family diversity on the Mexican coasts (Dreckmann \& Sentíes 2014). 


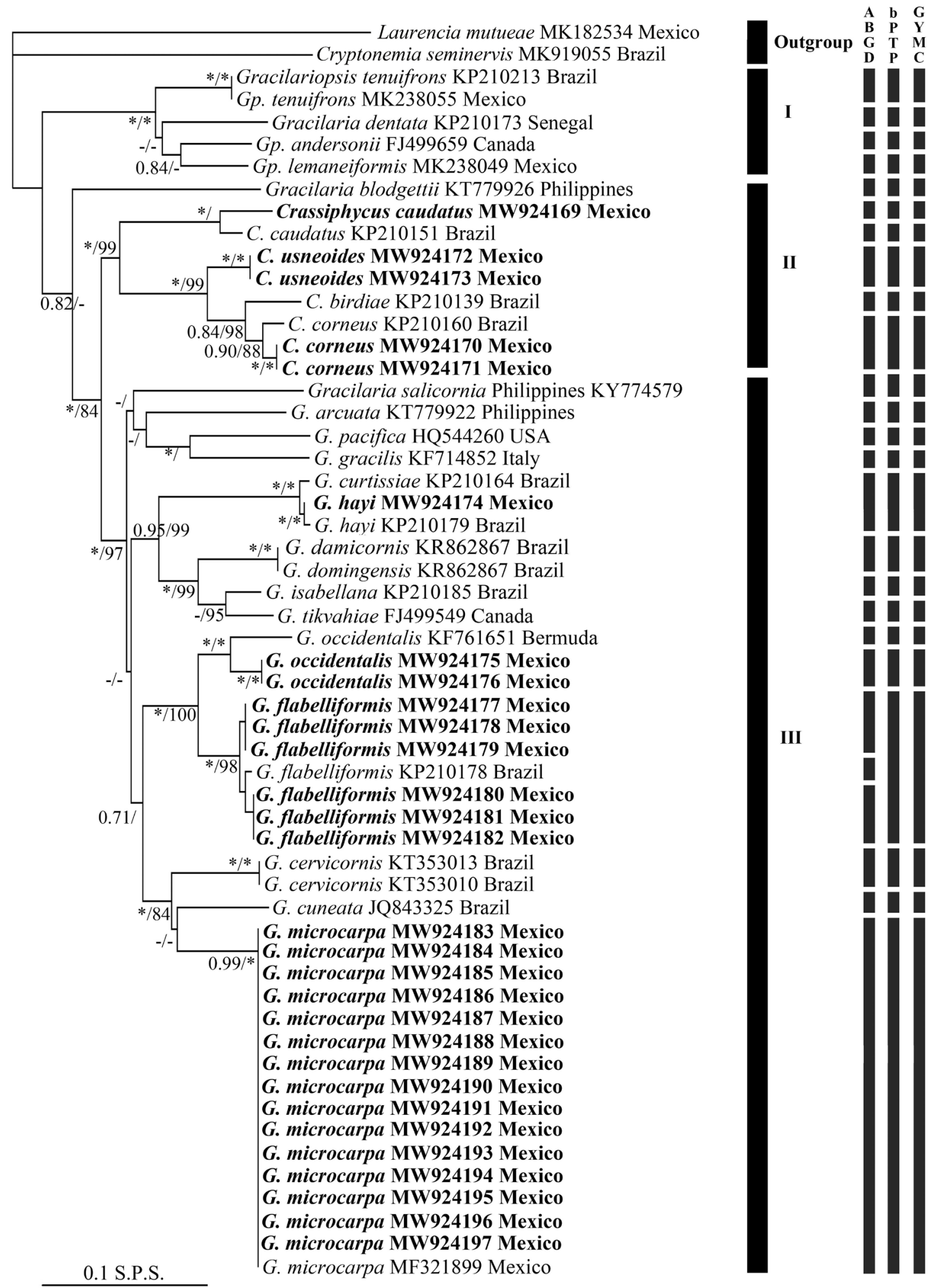

Figure 3. Maximum likelihood topology based on COI-5P sequences data. BI values (left) followed by ML bootstrap (right) on branches. Asterisks indicate full support $(\mathrm{BI}=1.0, \mathrm{ML}=100 \%)$, dashes indicate values below $70 \%$. Bars at the right of the tree indicate the results of the three species delimitations methods: Automatic Barcoding Gap Detection (ABGD), the General-Mixed-Yule-Coalescent (GMYC) and the Bayesian variant of Poisson Trees Processes model (bPTP). Sequences generated in this study are in boldface. S.P.S., substitutions per site. 


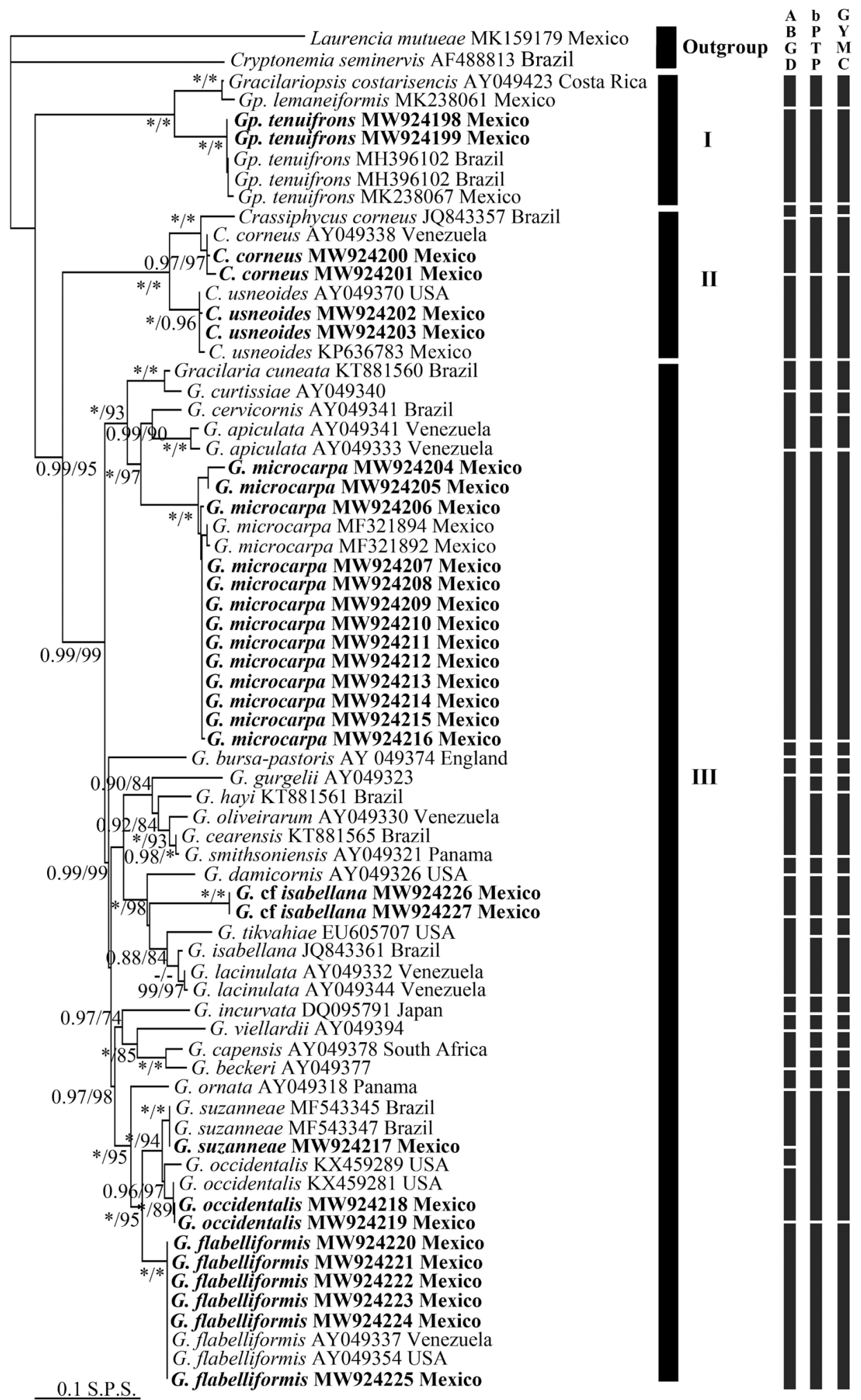

Figure 4. Maximum likelihood topology based on $r b c \mathrm{~L}$ sequences data. BI values (left) followed by ML bootstrap (right) on branches. Asterisks indicate full support $(\mathrm{BI}=1.0, \mathrm{ML}=100 \%)$, dashes indicate values below $70 \%$. Bars at the right of the tree indicate the results of the three species delimitations methods: Automatic Barcoding Gap Detection (ABGD), the General-Mixed-Yule-Coalescent (GMYC) and the Bayesian variant of Poisson Trees Processes model (bPTP). Sequences generated in this study are in boldface. S.P.S., substitutions per site. 
Recently, Hernández et al. (2020) demonstrated, with molecular evidence, that specimens morphologically identified as Gp. lemaneiformis from Yucatan Peninsula correspond to Gp. tenuifrons and it is distributed along Atlantic Mexican coast, and probably this species is the only distributed in the area.

Our results suggest a dramatic reduction of the floristic diversity known for the family in the Yucatan Peninsula. Of the 30 species currently recorded, our investigation can only support the phylogenetic identity of ten species, including two new records, despite our having sequenced specimens with the morphological characteristics corresponding to most of the reported species, especially those described by Dreckmann (2012). Of the confirmed species in our study, only the species of Crassiphycus (except C. crassissimus) and Gp. tenuifrons were consistent with those proposed by Dreckmann \& Sentíes (2014) and Hernández et al. (2020), respectively. Of the species of Gracilaria, none of those proposed by Dreckmann \& Sentíes (2014) was confirmed by our results. In fact, all these morphospecies turned out to be morphotypes of G. flabelliformis or G. microcarpa (recently described by Dreckmann et al. 2018). Both species are very abundant in the area, the first of flattened thalli and the second with cylindrical thalli. Except for G. suzanneae and G. hayi, originally described from Brazil (Soares et al. 2018) and Panama (Gurgel et al. 2004), respectively, which constitute new records for the Mexican Atlantic coasts; the rest of these Gracilaria species had already been previously recorded in the area. Gracilaria isabellana has been previously recorded from the coast of Veracruz, but although we found at the Yucatan Peninsula specimens morphologically very similar to what we had called $G$. cf isabellana, phylogenetic analysis and the results with DNA species delimitation methods suggested that these specimens may consist of an undescribed species. Additional morphological observations and sequence data are required to confirm its true identity.

For the rest of the morphospecies (García-García et al. 2020) of Gracilariaceae recorded for the Yucatan Peninsula and not confirmed in our study, eleven of them have type localities outside the Western Atlantic. G. armata, G. bursa-pastoris, G. gracilis, G. multipartite, and Gp. longissima have type localities in the European Atlantic and Mediterranean Sea; G. pacifica I.A. Abbott, Gp. andersonii, Gp. costaricensis and Gp. sjoestedtii in the American Pacific; and G. debilis and G. follifera in the Indian Ocean; which present a disjunct distribution, that is, an area of distribution interrupted by a geographical barrier (oceanic or continental). This type of distribution has been of great interest because geographic barriers can be the cause of evolutionary divergence processes between the populations involved, causing speciation. For example, regarding the Gracilariopsis species, Hernández et al. (2020) showed that the above-mentioned species are not present in the Mexican Atlantic, and that these records probably correspond molecularly to Gp. tenuifrons. So, the disjunct distribution of these species was ruled out. The morphological similarity between Gracilariopsis species is the main cause of misidentifications, which in turn leads to the wrong definition of their alleged disjunct distribution ranges and the overestimation of specific richness. This is a problem that may be occurring with Gracilaria species whose records in the American Atlantic do not correspond to their areas of distribution. However, another problem that could be the explanation of disjunct distribution for some species of Gracilariaceae family is the introduction of non-native species. Thus, the phylogenetic identified of these records not only help us clarify their taxonomic status, also their biogeographic processes.

Another important factor to consider in the molecular identification of the species found in this study is that the values of interspecific distance between them. In some cases, such as Gracilaria hayi, G. suzanneae, and G. curtissiae, the values of the interspecific distances ranged between 0.8 and $1.5 \%$, which is less than the range of interspecific values proposed by Gurgel et al. (2004) to delimit species of Gracilariaceae (from 2 to $3.4 \%$ ). From our results, a morphometic study of these species could provide additional evidence to support their phylogenetic independence, as it was in the case of Crassiphycus species, previously considered as cryptic species and currently discriminated by morphometric analysis (Vilchis et al. 2019, 2020).

Considering the values of the interspecific distances, the morphological similarity between several species in the Gracilariaceae, and the results using DNA species delimitation methods, it seems that some species in the family have been wrongly described as new diversity; consequently, they must be critically reviewed. For example, in a very recent study (Lyra et al. 2021), the floristic diversity for the Gracilariaceae species from Brazil was discussed under morphological and molecular evidence. Consequently, genera previously described as independent from Gracilaria 
due to their paraphyletic position in the phylogeny (Gurgel et al. 2018, 2020), have been merged back into a single genus (Lyra et al. 2021). Crassiphycus was one of the genera included in a broadly circumscribed Gracilaria sensu lato proposed by Lyra et al. (2021). However, from our phylogenetic analysis, we recognize Crassiphycus as an independent genus of Gracilaria. Likewise, in the study by Lyra et al. (2021), Crassiphycus usneoides was not included within the diversity of Gracilariaceae in Brazil, because they did not molecularly confirm its presence and discussed, in agreement with Núñez-Resendiz et al. (2015), the difficulty of recognizing them morphologically. Previously, $C$. usneoides was included as part of a complex of cryptic species along with $C$. corneus by Núñez-Resendiz et al. (2015), both species with type localities in Brazil. In their study they described that within the morphological spectrum of the two species included in the complex, there were two genetically independent entities, although morphologically indistinguishable. Recently, Vilchis et al. $(2019,2020)$ was able to discriminate both genetic entities, by applying morphometric techniques, both by the diameter in the middle and apical portion of the thallus (significantly larger in C. usneoides than in C. corneus) and by the shape of the cells (narrower in C. usneoides). Given that C. corneus and C. usneoides were circumscribed only with morphological evidence, the characters that were used for discriminated them overlap between the two species, so it may be that in Brazil only C. corneus is distributed. However, our morphological and molecular results do support the presence of both species in the Yucatan Peninsula.

In conclusion, based on our current results, we could detect the phylogenetic identity to 10 species from the molecular analysis of nine morphospecies. These identities correspond to species previously recorded and two new records for the Yucatan Peninsula. The study demonstrated that the molecular assessment has proved to be very useful for the diversity evaluation, thus, the future phylogenetic identifies for the rest of morphospecies recorded in the area will allow a better approximation of Gracilariaceae diversity species.

\section{Acknowledgments}

We are grateful to Dr Michael J. Wynne (University of Michigan) for his contribution with a critical review of this manuscript. We thank to the anonymous reviewers. This work was supported by the projects: UAMI-CBS2019-2022: session 15.18-281118 and UAMI-CA-117, SEP-PRODEP. MIV, OEH and CAPO thank to the Consejo Nacional de Ciencia y Tecnología for the scholarship granted.

\section{Supplementary material}

Supplemental data for this article can be accessed here: https://doi.org/10.17129/botsci.2915

\section{Literature cited}

Ardito MS, Núñez-Resendiz ML, Dreckmann KM, Sentíes A. 2017. Gracilaria falconii sp. nov. (Gracilariales, Rhodophyta): a new species with flat axes from Venezuela. Phytotaxa 292: 271-278. DOI: https://doi.org/10.11646/ phytotaxa.292.3.7

Bird CJ, McLachlan J. 1982. Some underutilized taxonomic criteria in Gracilaria (Rhodophyta, Gigartinales). Botanica Marina 25: 557-562. DOI: https://doi.org/10.1515/botm.1982.25.12.557

Byrne K, Zuccarello GC, West J, Liao ML, Kraft GT. 2002. Gracilaria species (Gracilariaceae, Rhodophyta) from southeastern Australia, including a new species, Gracilaria perplexa sp. nov.: morphology, molecular relationships and agar content. Phycological Research 50: 295-311. DOI: https://doi.org/10.1111/j.1440-1835.2002.tb00162.x

Cohen S, Faugeron S, Martínez EA, Correa JA, Viard F, Destombe C, Valero M. 2004. Molecular identification of two sibling species under the name Gracilaria chilensis. Journal of Phycology 40: 742-747. DOI: https://doi. org/10.1111/j.1529-8817.2004.03203.x

Dreckmann KM. 2012. Los géneros Gracilaria e Hydropuntia (Gracilariaceae, Rhodophyta) en las costas del Golfo de México y Caribe. In: Sentíes A, Dreckmann KM, eds. Monografias Ficológicas Volumen 4. Ciudad de México: 
Universidad Autónoma Metropolitana - Iztapalapa y Universidad de la Laguna. pp. 111-203. ISBN: 978-607-477689-8

Dreckmann KM, Sentíes A. 2014. Biodiversidad de Gracilariaceae (Rhodophyta) en México. Revista Mexicana de la Biodiversidad 85: 69-75. DOI: https://doi.org/10.7550/rmb.40717

Dreckmann K.M, Núñez-Resendiz ML, Sentíes A. 2018. Gracilaria microcarpa sp. nov. (Gracilariaceae, Rhodophyta) from the southwestern Gulf of Mexico. Botanica Marina 61: 115-125. DOI: https://doi.org/10.1515/bot-2017$\underline{0068}$

Drummond AJ, Suchard MA, Xie D, Rambaut A. 2012. Bayesian phylogenetic with BEAUTi and the BEAST 1.7. Molecular Biology and Evolution 29: 1969-1973. DOI: https://doi.org/10.1093/molbev/mss075

Freshwater DW, Rueness J. 1994. Phylogenetics relationships of some European Gelidium (Gelidiales, Rhodophyta) species based on $r b c \mathrm{~L}$ nucleotide sequences analysis. Phycologia 33: 187-194. DOI: https://doi.org/10.2216/ i0031-8884-33-3-187.1

García-García AME, Cabrera-Becerril E, Núñez-Resendiz ML, Dreckmann KM, Sentíes A. 2020. Actualización taxonómica de las algas rojas (Rhodophyta) marinas bentónicas del Atlántico mexicano. Acta Botanica Mexicana 127: e1677. DOI: https://doi.org/10.21829/abm127.2020.1677

Guiry MD, Guiry GM. 2021. AlgaeBase. World-wide electronic publication. Galway: National University of Ireland. https://www.algaebase.org (accessed April 20, 2021).

Guiry MD, Norris JN, Fredericq S, Gurgel CFD. 2018. Crassiphycus Guiry, Gurgel, J.N.Norris \& Fredericq, gen. nov., a replacement name for Crassa Gurgel, J.N.Norris \& Fredericq, nom. inval. (Gracilariaceae, Rhodophyta), with some additional nomenclatural notes. Notulae Algarum 82: 1-4.

Gurgel CFD, Fredericq S. 2004. Systematics of the Gracilariaceae (Gracilariales, Rhodophyta): A critical assessment based on $r b c$ L sequence analyses. Journal of Phycology 40: 138-159. DOI: https://doi.org/10.1111/j.00223646.2003.02-129.x

Gurgel CFD, Fredericq S, Norris JN. 2004. Molecular systematics and taxonomy of flattened species of Gracilaria Greville (Gracilariaceae, Gracilariales, Rhodophyta) from the Western Atlantic. In: Abbott IA, McDermid KJ, eds. Taxonomy of Economic Seaweeds with Reference to the Pacific and other Locations Volume IX. EUA: Hawaii Sea Grant College Program. pp. 159-200. ISBN: 1-929054-00-9

Gurgel CFD, Liao LM, Fredericq S, Hommersand MH. 2003. Systematics of Gracilariopsis (Gracilariales, Rhodophyta) based on $r b c$ L sequence analyses and morphological evidence. Journal of Phycology 39: 154-171. DOI: https://doi.org/10.1046/j.1529-8817.2003.02046.x

Gurgel CFD, Norris JM, Schmidt WE, Nhu Le H, Fredericq S. 2018. Systematics of the Gracilariales (Rhodophyta) including new subfamilies, tribes, subgenera, and two new genera, Agarophyton gen. nov. and Crassa gen. nov. Phytotaxa 374: 001-023. DOI: https://doi.org/10.11646/phytotaxa.374.1.1

Gurgel CFD, Soares LP, Norris JN, Fujii MT, Schmidt WE, Fredericq S. 2020. Molecular systematics of Crassiphycus and Hydropuntia (Gracilariales, Rhodophyta) with the description of poorly known taxa in the Western Atlantic Ocean. European Journal of Phycology 56: 216-229. DOI: https://doi.org/10.1080/09670262.2020.181 $\underline{4424}$

Hall TA. 1999. BioEdit a user-friendly biological sequence alignment editor and analysis program for Windows 95/98/NT. Nucleic Acids Symposium 41: 95-98.

Hardesty DM, Freshwater DW. 2018. Studies of North Carolina marine algae XIV: increased diversity of flattened offshore Gracilaria (Gracilariales, Rhodophyta) species revealed by DNA sequences of contemporary specimens and the G. mammillaris holotype. Botanica Marina 61: 407-413. DOI: https://doi.org/10.1515/bot$\underline{2017-0120}$

Hernández OE, Dreckmann KM, Núñez-Resendiz ML, Vilchis MI, Sentíes A. 2020. Gracilariopsis lemaneiformis (Gracilariaceae, Rhodophyta) in the Mexican coasts: a case of disjunct distribution? American Journal of Plant Sciences 11: 111-124. DOI: https://doi.org/10.4236/ajps.2020.112009

Kim GH, Shim JB, Klochkova TA, West JA, Zuccarello GC. 2008. The utility of proteomics in algal taxonomy: 
Bostrychia radicans/B. moritziana (Rhodomelaceae, Rhodophyta) as a model study. Journal of Phycology 44: 1519-1528. DOI: https://doi.org/10.1111/j.1529-8817.2008.00592.x

Kumar S, Stecher G, Li M, Kniyaz C, Tamura K. 2018. MEGA X: Molecular Evolutionary Genetics Analysis across computing platforms. Molecular Biology and Evolution 35: 1547-1549. DOI: https://doi.org/10.1093/molbev/ $\underline{\mathrm{msy} 096}$

Le HN, Muangmai N, Kheauthong S, Sun Z, Zuccarello GC. 2020. Gracilaria phuquocensis sp. nov., a new flattened Gracilaria species (Gracilariales, Rhodophyta), previously recognized as G. mammillaris, from the southern coast of Vietnam. Phycological Research 68: 50-56. DOI: https://doi.org/10.1111/pre.12394

Lyra GM, Costa ES, De Jesús PB, Matos JCG, Caires TA, Oliveira MC, Oliveira EC, Nunes JMC, Davis CC. $2015 \mathrm{a}$. Phylogeny of Gracilariaceae (Rhodophyta): evidence from plastid and mitochondrial nucleotide sequences. Journal of Phycology 51: 356-366. DOI: https://doi.org/10.1111/jpy.12281

Lyra GM, Gurgel CFD, Costa ES, De Jesus PB, Matos JCG, Caires TA, Oliveira MC, Oliveira EC, Davis EC, Castro JMC. 2015b. A new tropical species of Gracilariaceae (Rhodophyta, Gracilariales): Gracilaria silviae sp. nov. Phytotaxa 222: 199-210. https://doi.org/10.11646/phytotaxa.222.3.3

Lyra GM, Gurgel CF, Costa ES, De Jesús PB, Oliveira MC, Oliveira EC, Davis CC, Nunes JMC. 2016. Delimitating cryptic species in the Gracilaria domingensis complex (Gracilariaceae, Rhodophyta) using molecular and morphological data. Journal of Phycology 52: 997-1017. DOI: https://doi.org/10.1111/jpy.12456

Lyra GM, Nunes JMC, Pestana MES, De Matos JCG, Caires TA, De Jesús PB, Costa ES, Oliveira MC. 2021. Diversity of Gracilariaceae (Rhodophyta) in Brazil: integrating morphological and molecular data. Phytotaxa 496: 001-053. DOI: https://doi.org/10.11646/phytotaxa.496.1.1

Milne I, Lindner D, Bayer M, Husmeier D, McGuire G, Marshall DF, Wright F. 2009. TOPALi v2: a rich graphical interface for evolutionary analyses of multiple alignments on HPC clusters and multi-core desktops. Bioinformatics 25: 126-127. DOI: https://doi.org/10.1093/bioinformatics/btn575

Muangmai N, Yamagishi Y, Zuccarello GC, Chirapart A, Lewmanomont K. 2014a. Transferring Gracilaria irregularis (Grcilariaceae, Rhodophyta) from Thailand to Gracilariopsis based on morphological and molecular analyses. Phycological Research 62: 29-35. DOI: https://doi.org/10.1111/pre.12032

Muangmai N, Zuccarello GC, Noiraksa T, Lewmanomont K. 2014b. A new flat Gracilaria: Gracilaria lantaensis sp. nov. (Gracilariales, Rhodophyta) from the Andaman coast of Thailand. Phycologia 53: 137-145. DOI: https://doi. org/10.2216/13-215.1

Núñez-Resendiz ML, Dreckmann KM, Sentíes A, Díaz-Larrea J, Zuccarello GC. 2015. Genetically recognizable but not morphologically: the cryptic nature of Hydropuntia cornea and H. usneoides (Gracilariales, Rhodophyta) in the Yucatan Peninsula. Phycologia 54: 407-416. DOI: https://doi.org/10.2216/15-009.1

Núñez-Resendiz ML, Zuccarello GC, Dreckmann KM, Sentíes A. 2016. Phylogeography of Hydropuntia cornea/ Hydropuntia usneoides complex (Gracilariales, Rhodophyta) in the Yucatan Peninsula. Phycologia 56: 14-20. DOI: https://doi.org/10.2216/16-46.1

Oliveira EC, Alveal K, Anderson R. 2000. Mariculture of the agar-producing Gracilarioid red algae. Reviews in Fisheries Science 8:345-78. DOI: https://doi.org/10.1080/10408340308951116

Ortega MM, Godínez JL, Garduño-Solórzano G. 2001. Catálogo de algas bentónicas de las costas mexicana del Golfo de México y Mar Caribe. Ciudad de México: Cuadernos del Instituto de Biología, Universidad Nacional Autónoma de México ISBN: 968-36-9566-3

Pons J, Barraclough TG, Gómez-Zurita J, Cardoso A, Duran DP, Hazell S, Kamoun S, Sumlin WD, Vogler AP. 2006. Sequences-based species delimitation for the DNA taxonomy of undescribed insects. Systematic Biology 55: 595609. DOI: https://doi.org/10.1080/10635150600852011

Puillandre N, Lambert A, Brouillet S, Achaz G. 2012. ABGD, Automatic barcode gap discovery for primary species delimitation. Molecular Ecology 21: 1864-1877. DOI: https://doi.org/10.1111/j.1365-294X.2011.05239.x

Rambaut A, Suchard MA, Xie D, Drummond AJ. 2014. Tracer v1.6. http://beast.bio.ed.ac.uk/Tracer

Ronquist F, Teslenko M, Van Der Mark P, Ayres DL, Darling A, Hohna S, Larget B, Liu L, Suchard MA, Huelsen- 
beck JP. 2012. MrBayes 3.2: Efficient Bayesian phylogenetic inference and model choice across a large model space. Systematic Biology 61: 539-542. DOI: https://doi.org/10.1093/sysbio/sys029

Santelices B, Valera D. 1993. Intra-clonal variation in the red seaweed Gracilaria chilensis. Marine Biology 116: 543-552. DOI: https://doi.org/10.1007/BF00355472

Saunders GW. 2005. Applying DNA barcoding to red macroalgae: a preliminary appraisal holds promise for feature application. Philosophical Transactions of the Royal Society B 360: 1879-1888. DOI: https://doi.org/10.1098/ rstb.2005.1719

Saunders GW. 2009. Routing DNA barcoding of Canadian Gracilariales (Rhodophyta) reveals the invasive species Gracilaria vermiculophylla in British Columbia. Molecular Ecology Resources 9: 140-150. DOI: https://doi. org/10.1111/j.1755-0998.2009.02639.x

Shimada S, Horiguchi T, Masuda M. 1999. Phylogenetic affinities of genera Acanthopeltis and Yatabella (Gelidiales, Rhodophyta) inferred from molecular analysis. Phycologia 3: 528-540. DOI: https://doi.org/10.2216/i0031-888438-6-528.1

Soares LP, Gurgel CFD, Fujii MT. 2018. Gracilaria suzanneae sp. nov. (Gracilariales, Rhodophyta), a new flattened species from northeast Brazil based on morphological and molecular evidence. Phycologia 57: 345-353. DOI: https://doi.org/10.2216/17-102.1

Stamatakis A. 2006. RAxML-VI-HPC: maximum likelihood-based phylogenetic analyses with thousands of taxa and mixed models. Bioinformatics 22: 2688-2690. DOI: https://doi.org/10.1093/bioinformatics/btl446

Vilchis MI, Neustupa J, Dreckmann KM, Quintanar A, Sentíes A. 2019. Discrimination of the species of the Crassiphycus corneus/C. usneoides complex (Gracilariaceae, Rhodophyta) through geometric morphometric analysis. Nova Hedwigia 109: 1-11. https://doi.org/10.1127/nova_hedwigia/2019/0543

Vilchis MI, Dreckmann KM, Quintanar A, Sentíes A. 2020. Análisis morfométrico de las especies simpátricas del complejo Crassiphycus corneus-C. usneoides (Gracilariaceae, Rhodophyta) en las costas mexicanas del Golfo de México y Mar Caribe. Acta Botánica Mexicana 127: e1596. DOI: https://doi.org/10.21829/abm127.2020.1596

Wang HW, Kawaguchi S, Horiguchi T, Masuda M. 2000. Reinstatement of Grateloupia catenata (Rhodophyta, Halymeniaceae) on the basis of morphology and $r b c \mathrm{~L}$ sequences. Phycologia 39: 228-237. DOI: https://doi. org/10.2216/10031-8884-39-3-228.1

Yang EC, Kim MS, Geraldino PJL, Sahoo D, Shin JA, Boo SM. 2008. Mithocondrial cox 1 and plastid $r b c$ L fenes of Gracilaria vermiculophylla (Gracilariaceae, Rhodophyta). Journal of Applied Phycology 20: 161-168. DOI: https://doi.org/10.1007/s10811-007-9201-8

Yang MY, Geraldino PJL, Kim MS. 2013. DNA barcode assessment of Gracilaria salicornia (Gracilariaceae, Rhodophyta) from southeast Asia. Botanical Studies 54: 27. DOI: https://doi.org/10.1186/1999-3110-54-27

Zhang J, Kapli P, Pavlidis P, Stamatakis A. 2013. A general species delimitation method with applications to phylogenetic placements. Bioinformatics 29: 1969-1973. DOI: https://doi.org/10.1093/bioinformatics/btt499

\footnotetext{
Associate editor: José Antonio Zertuche González

Author contributions: MIV, conceptualization, field work, formal analysis, investigation, writing - reviewing and editing; KMD, investigation, writing - original draft preparation, reviewing and editing; OEH, investigation, writing - reviewing and editing; CAPO, molecular analysis, writing - reviewing and editing; MLNR, investigation, writing- original draft preparation, reviewing and editing; AS, field work, investigation, writing - reviewing, editing, project administration, and funding acquisition.
} 